\title{
Governance and Human Capital in Italian Co-operative and Popular Banks: Managing the Complexity ${ }^{*}$
}

\author{
Candida Bussoli \\ University Lum Jean Monnet, Casamassima, Italy \\ Claudio Giannotti \\ Libera Università Maria Ss. Assunta, Roma, Italy
}

\begin{abstract}
This paper aims to investigate the existence of a statistically significant relationship between performance and loan quality variables and the number of employees, the size of the board, and the number of committees in Italian co-operative and popular banks, in the years from 2010 to 2012. The analysis method is based on multivariate panel regressions models. The main results of the paper are related to the existence of a positive relationship between the loan quality and the number of committees and of employees: As the number of employees (proxy of the size and complexity of the structure) and committees (proxy for the complexity of the board) grows, the loan quality worsens. The number of committees also shows a negative relationship with return on average equity. The main results of the paper suggest to manage and reduce the complexity of the governance structure of co-operative and popular banks.
\end{abstract}

Keywords: corporate governance, co-operative banks, popular banks, human capital, management

\section{Introduction}

In the new market environment, banks operating in the field of cooperative credit are able to maintain strong local and retail banking vocation and are able to assert their role as local banks (Goglio \& Alexopulos 2014), even in adverse economic periods (Birchall \& Ketilson, 2009; Groeneveld \& De Vries, 2009; Ayadi, Schmidt, \& Carbó Valverde, 2009).

Co-operative banks and popular banks have small propensity to take risky choices thanks to their proximity to customers/members and the effective understanding of their needs and credit worthiness.

The mentioned aspects represent strong points for banks operating in the cooperative credit system, but these banks are also characterized by weak points, such as a limited number of options in raising capital and a complex governance model, exposed to unstable conditions, that can also affect negatively the performance and the efficiency of banks (Fonteyne, 2007; Mottura, 2011).

\footnotetext{
* This paper is the result of a joint effort and a continuous exchange of ideas among the authors. The individual parts are attributed as follows: Candida Bussoli has written "Literature and Research Hypotheses", "Methodology", "Sample and Data", and "Results"; Claudio Giannotti has written "Introduction" and "Conclusions".

Candida Bussoli, associate professor of Financial Markets and Institutions at the University Lum Jean Monnet, Casamassima (Bari), Italy.

Claudio Giannotti, full professor of Financial Markets and Institutions at the Libera Università Maria Ss. Assunta, Roma, Italy.

Correspondence concerning this article should be addressed to Candida Bussoli, the University Lum Jean Monnet, SS $100 \mathrm{~km}$ 18, Casamassima (Bari) 70010, Italy.
} 
The existence of potential conflicts of interest among shareholders (who have property rights, are involved in the governance of the company, and are also customers and employees of cooperatives), the substantial absence of a market for corporate control, and the divergence of interests between banks and federations are some of the main problems that can damage the formulation of proper governance practices in the cooperative credit system.

The factors of instability are important for the popular banks, due to the high dimension of some banks (Jassaud, 2014). The main issue is therefore referred to the suitability of the governance model of popular banks to fulfill the needs of banks that can reach even elevated size. Some ownership features, such as one vote per member, or membership requirements may hamper effective governance, once the bank grows beyond a certain size, may discourage the participation of members in the life of the bank and reduce the ability to control them, allowing the concentration of power and reducing the effectiveness of the monitoring.

It makes clear the importance of governance and the role of human capital involved (Goglio \& Alexopulos, 2014), even as employees. Especially for small sized banks, employees can influence the performance and the efficiency of corporate governance due to the existence of the dual capacity as owners/employees.

This paper takes into consideration literature that attaches importance to the structure and composition of the board of banks (board size, the presence of non-executive directors, the presence of women, etc.), as well as some characteristics related to the organization of the board (number of committees, frequency of meetings, and participation in meetings). The reference literature, especially internationally, is wide, but it comes to mixed results (Adams \& Mehran, 2003; 2005; 2008; Cornett, McNutt, \& Tehranian, 2009; Erkens, Hung, \& Matos, 2012; Fahlenbrach \& Stulz, 2012; Ahrens, Schweickert, \& Zenker, 2011; Beltratti \& Stulz, 2011).

The paper aims to investigate the presence of a relationship of dependency between performance (return on average assets - ROAA and return on average equity - ROAE) and loan quality variables (impaired loans on gross loans) and governance and human capital variables: the number of employees, the size of the board, and the number of committees of co-operative and popular banks.

The analysis method is based on multivariate panel regressions. The sample is composed of 24 Italian co-operative banks and 24 Italian popular banks, in a three years period from 2010 to 2012.

The main results of the paper are related to the existence of a positive relationship between the loan quality and the number of committees and employees: As the number of employees (proxy of the size and complexity of the structure) and committees (proxy for the complexity of the board) grows, the loan quality worsens.

The number of employees has a negative relationship with ROAA as well; the number of committees also shows a negative relationship with ROAE.

The main implications of the results of the paper suggest to manage and reduce the complexity of the governance structure of co-operative and popular banks, in order not to lose the link between the values of mutuality and the active participation of members and employees and not to lose the strength of local banks.

The work is structured as follows: The second section presents the literature review leading to the research hypotheses; the third section explains the research methodology; the fourth section describes the sample under analysis; the fifth discusses the results; and the final section presents brief conclusions and implications of the phenomenon under investigation.

\section{Literature and Research Hypotheses}

The cooperative banks have been able to assert their role as local banks even in adverse economic periods 
(Birchall \& Ketilson, 2009; Groeneveld \& De Vries, 2009; Ayadi et al., 2009). The reasons of the success can be summarized in the following points: strong local roots and retail banking, which allow for greater stability of fundraising; ability to limit the credit rationing and rising rates; and low propensity to taking risky choices determined, on one hand, by the strong local roots and proximity to customers/partners - that enable a better understanding of the needs and risks of borrowers - on the other hand, being less subject to problems of substitutability of assets (Drake \& Llewellyn, 2001), less subject to the pressure of management choices of short-term, and less subject to the pressure of profit maximization.

The governance model of these banks, however, is a complex model, exposed to risks and weaknesses (Mottura, 2011). The governance of co-operative and popular banks is characterized by the presence of customers and partners who are involved in the governance structure of the bank and this allows a broader consensus and prevents the risk of focusing attention only on one type of stakeholders, as the basis of the partners is widely diversified and able to represent different instances and interests (Fonteyne, 2007). These aspects present, however, a potential conflict of interest as the members have property rights, but they are also depositors, borrowers, and employees.

For popular banks, the theme that is relevant is referred also to the suitability of the governance model to meet the needs of companies that can assume even considerable size: In such cases, the one-vote and the acceptance clauses may discourage the participation of members in the life of the bank and reduce the ability to control them, favoring the concentration of power and reducing the effectiveness of governance.

What is claimed reveals the importance of the analysis on the possible relationships between corporate governance of banks operating in the cooperative credit system and performance and credit quality (Boscia, Bussoli, Cotugno, \& Stefanelli, 2012).

The literature on the relationship between corporate governance and performance in financial and non-financial firms has produced mixed results.

A first issue extensively investigated concerns the size of the board. Adams and Mehran (2003) found that banking companies have larger boards if compared to industrial companies, owing to the complex organizational structure. In a later work, the authors examined the relationship between the size of the boards of banks and their performance, approximated by a measure of Tobin's Q (Adams \& Mehran, 2005). In contrast to the findings noted for non-financial companies, they found a non-negative relationship between the natural logarithm of board size and Tobin's Q.

Belkhir (2009) analyzed the relationship between board size and performance in a sample of banks and financial companies and found a positive relationship between performance and size of the board.

In contrast to previous work, Mayur and Saravanan (2006) noted that the size of the board has no effect on the performance of banks.

The only analysis on the board's size does not allow to capture some of the determinants of internal dynamics that characterize the functioning of the board. The interests of shareholders and other stakeholders, as well as the distribution of tasks and balance of powers, can only be investigated by evaluating some profiles of the composition of the board. In this context, a first determining factor is the typology of directors: external or independent directors, executive and non-executive directors, directors who hold managerial positions in various boards, directors of different ethnicity and nationality, or directors of female gender.

Following Larcker, Richardson, and Tuna (2007) and Grove, Patelli, Victoravich, and Xu (2010) have examined multiple factors of corporate governance and the relationship of these factors with the bank's 
performance - in terms of quality of revenues, ROA, and Tobin's Q - and with the loan quality. The results show a worse performance, when the board members are less young and less independent and the bank has a high degree of leverage.

Love and Rachinsky (2007) examined the relationship between bank ownership and some aspects of governance in the Russian and Ukrainian banks and they also focused on the relationship between governance and performance. The results of the study allow to argue that corporate governance has, at most, a second order effect on the management performance of banks in Russia and Ukraine.

In more recent years, the focus is on the examination of the relationship between corporate governance and performance in the period of the financial crisis: Also in this case, the results are not unique and do not get robust empirical evidence about the failure or success of bank governance in adverse economic situations (Beltratti \& Stulz, 2009; 2011; Fahlenbrach \& Stulz, 2012).

The work of Peni and Vähämaa (2011) focuses on the impact of corporate governance on the performance of listed banks in the United States of America during the financial crisis. The results, referred to 2008, suggest that banks with strong governance mechanisms are associated with higher profitability.

Ahrens et al. (2011) showed that banks with strong governance mechanisms may have led to higher stock returns in the aftermath of the crisis, from March 2009 onwards, and that good governance may have mitigated the negative factors, such as the credibility of the banks, determined by financial crisis.

Erkens et al. (2012) provided empirical evidence about the influence of corporate governance on the performance of financial firms during the crisis, analyzing particularly the role of independent directors and influential shareholders. The analysis shows that financial firms with more independent boards and more institutional holdings obtained worse equity returns during the crisis period.

The literature on the relationship between corporate governance and performance in financial and non-financial firms has produced mixed results, often discordant, but feeds a growing debate regarding the importance of corporate governance to achieve conditions of sound and prudent management and overall performance.

Compared to the literature described above, the present work aims to analyze the significance of the size and organization of the board of directors (number of committees) in the context of the Italian banking market. It also considers the importance of the number of employees for the purpose of analyzing the impact of the complexity of the structure and numerousness of human capital on the performance and credit quality.

In particular, the research hypotheses are as follows:

HP1: There is a statistically significant relationship between size of the board and performance and credit quality of co-operative and popular banks;

HP2: There is a statistically significant relationship between number of committees of the board and performance and credit quality of co-operative and popular banks;

HP3: There is a statistically significant relationship between number of employees and performance and credit quality of co-operative and popular banks.

\section{Methodology}

Consistent with the literature, panel regression models are used to test the research hypotheses: The dependent variable is represented, in turn, by performance measures of an accounting nature.

The dependent variables are listed and described below: 
- ROAA reflects the efficiency with which the bank uses its assets to generate income and is calculated as the ratio between net income and the average value of total asset (Love \& Rachinsky, 2007; Abdulsamad \& Zulkafli, 2007; Weisbach, 1988; Adams \& Mehran, 2005);

- ROAE is the ratio between net income and average equity (Love \& Rachinsky, 2007; Abdulsamad \& Zulkafli, 2007; Weisbach, 1988);

- CREDET represents the quality of the loans of the bank and is calculated as the ratio of impaired loans to gross loans (Bussoli, 2013).

The independent variables are listed and described below:

- LBDIM is size of the board, measured by the natural logarithm of the number of members of the board (Adams \& Mehran, 2003; 2005; Belkhir, 2004; Mayur \& Saravanan, 2006);

- LNC is number of committees in the board, proxy for the complexity of the board, measured by the natural logarithm of the number of committees in the board;

- LNE is proxy of the size and complexity of the structure, measured by the natural logarithm of the number of employees.

The control variables are as follows:

- CR (capital ratio) represents the capital adequacy ratio according to Basel rules; the data, provided to the system by banks, are taken from the database Bankscope and it is a proxy of the bank's capital structure (Adams \& Mehran, 2005);

- GTL represents the growth of gross loans; the data are taken from the database Bankscope.

The analysis explores the existence of a statistically significant relationship among dependent variables whose measures are subsequent to the measures of independent and control variables, in order to reduce potential endogeneity problems. Corporate governance can be endogenous to performance, as banks with improved performance may decide to adopt stricter corporate governance mechanisms as a way to tell the system of their potential performance. Therefore, to reduce potential endogeneity problems, the study uses data on performance referring to the year subsequent to the measures of governance.

The panel regression model is as follows:

$$
Y_{i t}=\alpha+\beta_{1} \mathrm{LBDIM}_{i t}+\beta_{2} \mathrm{LCN}_{i t}+\beta_{3} T C R_{i t}+\beta_{4} \mathrm{LNE}_{i t}+\beta_{5} G T L_{i t}+\varepsilon_{i t}
$$

where $i$ identifies the individual sample observations; $Y_{i t}$ is the performance measure expressed through the independent variables; $\beta_{1}, \beta_{2}, \ldots$ are parameters to be estimated with the model; $\alpha$ is the constant of the model; and $\varepsilon_{i t}$ is the error.

For the pooled analysis, this paper runs multicollinearity and white heteroskedasticity test. The presence of heteroskedasticity determines the analysis with robust standard errors.

For fixed effects regressions, this paper tests the difference among intercepts: A low $p$-value determines the rejection of the null hypothesis that the model is adequate for the pooled analysis and supports the choice of the model with fixed effects.

For random effect regressions, this paper runs the Hausman test: A low $p$-value determines the rejection of the null hypothesis that the model with random coefficients is appropriate and consistent and confirms the validity of the use of an analysis with fixed effects. 


\section{Sample and Data}

The sample consists of 48 Italian banks: Twenty-four are cooperative banks and 24 are popular banks. Banks are located throughout the national territory and have different size of total asset, in order to represent the complex Italian cooperative credit system.

The analysis refers to the years 2010, 2011, and 2012. For the construction of some delayed variables, the series also includes the year 2009.

The accounting data of the sample are taken from the database Bankscope. The data relating to the governance of banks are taken from the financial statements and from the official websites.

\section{Results}

The results of the regression analysis are in Tables 1, 2, and 3.

Discussing the results referred to the research hypotheses, it is necessary to clarify that-following the robustness test carried out - the results referred to the regression analysis with fixed effects and robust standard errors are discussed in relation to the dependent variables CREDET and ROAA; the results referred to the regression analysis with robust random effects are discussed in relation to the dependent variable ROAE.

The first research hypothesis is not verified: A statistically significant relationship between the dependent variables and the size of the board is not observable (Tables 1, 2, and 3).

Table 1

Regression Models-Dependent Variable: CREDET

\begin{tabular}{lllllll}
\hline Variable & Pooled & Pooled robust & Fixed effect & Fixed effect robust $\begin{array}{l}\text { Random } \\
\text { effect }\end{array}$ & $\begin{array}{l}\text { Random } \\
\text { effect robust }\end{array}$ \\
\hline LBDIM & $-5.866^{* * *}$ & $-5.866^{* * *}$ & -3.788 & -3.788 & $-6.181^{* *}$ & $-6.181^{* * *}$ \\
& 2.051 & 1.551 & 5.558 & 3.129 & 2.919 & 2.011 \\
LCN & $2.812^{* * *}$ & $2.812^{* * *}$ & 1.648 & $1.648^{*}$ & $2.175^{* *}$ & $2.175^{* * *}$ \\
& 0.670 & 0.632 & 1.182 & 1.017 & 0.868 & 0.786 \\
CR & 0.068 & 0.068 & $0.285^{* * *}$ & $0.285^{* *}$ & 0.042 & 0.042 \\
& 0.045 & 0.035 & 0.103 & 0.139 & 0.045 & 0.050 \\
GTL & 0.008 & $0.008^{*}$ & 0.003 & 0.003 & 0.004 & 0.004 \\
& 0.007 & 0.004 & 0.007 & 0.008 & 0.006 & 0.005 \\
LNE & $-1.013^{* * *}$ & $-1.013^{* *}$ & $6.138^{* * *}$ & $6.138^{* *}$ & -0.625 & -0.625 \\
& 0.375 & 0.435 & 2.295 & 3.157 & 0.608 & 0.704 \\
CONST & $26.296^{* * *}$ & $26.296^{* * *}$ & -21.616 & -21.616 & $26.254^{* * *}$ & $26.254^{* * *}$ \\
& 4.350 & 4.027 & 21.313 & 22.806 & 6.375 & 5.825 \\
$N$ & 122.000 & 122.000 & 122.000 & 122.000 & 122.000 & 122.000 \\
$r 2$ & 0.181 & 0.181 & 0.132 & 0.132 & & 0.168 \\
$r 2 \_0$ & & & 0.015 & 0.015 & 0.168 & \\
\hline
\end{tabular}

Notes. Level of significance: $* * *$ is $1 \%$; ** is $5 \%$; and $*$ is $10 \%$.

The results referring to the size of the board are in conflict with the expectations and with the literature that, for the banking sector (Adams \& Mehran, 2005; Belkhir, 2004), revealed the presence of a non-negative dependency relationship between performance measures and governance variables.

Moving on to discuss the results relating to the second research hypothesis, it is possible to observe the presence of a statistically significant relationship between the number of committees and credit quality (Table 1). The relationship is positive, therefore, as the number of committees in the board increases, the value of the 
ratio between impaired loans and gross loans increases, showing a worse credit quality. The large number of committees affects credit quality.

Table 2

Regression Models-Dependent Variable: ROAE

\begin{tabular}{lllllll}
\hline Variable & Pooled & Pooled robust & Fixed effect & $\begin{array}{l}\text { Fixed effect } \\
\text { robust }\end{array}$ & $\begin{array}{l}\text { Random } \\
\text { effect }\end{array}$ & $\begin{array}{l}\text { Random } \\
\text { effect robust }\end{array}$ \\
\hline LBDIM & 2.595 & 2.595 & 16.814 & 16.814 & 2.749 & 2.749 \\
& 2.875 & 2.405 & 13.967 & 11.980 & 3.020 & 2.631 \\
LCN & $-2.951^{* * *}$ & $-2.951^{* * *}$ & $-6.503 * *$ & -6.503 & $-3.012^{* * *}$ & $-3.012^{* * *}$ \\
& 0.959 & 0.984 & 2.961 & 4.237 & 1.006 & 1.093 \\
CR & $-0.140^{* *}$ & -0.140 & -0.314 & $-0.314 *$ & $-0.139 * *$ & $-0.139 * *$ \\
& 0.064 & 0.100 & 0.259 & 0.173 & 0.066 & 0.059 \\
GTL & -0.007 & -0.007 & 0.012 & 0.012 & -0.006 & -0.006 \\
& 0.010 & 0.014 & 0.018 & 0.018 & 0.010 & 0.006 \\
LNE & -0.577 & -0.577 & -7.240 & -7.240 & -0.598 & -0.598 \\
CONST & 0.543 & 0.485 & 5.764 & 5.401 & 0.572 & 0.540 \\
& 4.096 & 4.096 & 12.444 & 12.444 & 3.864 & 3.864 \\
$N$ & 151 & 6.138 & 53.485 & 32.847 & 6.454 & 6.039 \\
$r 2$ & 124.000 & 124.000 & 124.000 & 124.000 & 124.000 & 124.000 \\
$r 2 \_0$ & 0.168 & 0.168 & 0.113 & 0.113 & & 0.168 \\
\hline
\end{tabular}

Notes. Level of significance: *** is $1 \%$; ** is $5 \%$; and * is $10 \%$.

Table 3

Regression Models-Dependent Variable: ROAA

\begin{tabular}{|c|c|c|c|c|c|c|}
\hline Variable & Pooled & Pooled robust & Fixed effect & $\begin{array}{l}\text { Fixed effect } \\
\text { robust }\end{array}$ & Random effect & $\begin{array}{l}\text { Random effect } \\
\text { robust }\end{array}$ \\
\hline \multirow[t]{2}{*}{ LBDIM } & 0.195 & 0.195 & 1.249 & 1.249 & 0.228 & 0.228 \\
\hline & 0.229 & 0.210 & 1.021 & 0.787 & 0.260 & 0.255 \\
\hline \multirow[t]{2}{*}{$\mathrm{LCN}$} & $-0.231 * * *$ & $-0.231 * *$ & $-0.520 * *$ & -0.520 & $-0.246 * * *$ & $-0.246^{* * *}$ \\
\hline & 0.076 & 0.078 & 0.216 & 0.330 & 0.086 & 0.095 \\
\hline \multirow[t]{2}{*}{$\mathrm{CR}$} & $-0.011 * *$ & -0.011 & $-0.034^{*}$ & $-0.034^{*}$ & $-0.011^{*}$ & -0.011 \\
\hline & 0.005 & 0.010 & 0.019 & 0.015 & 0.005 & 0.007 \\
\hline \multirow[t]{2}{*}{ GTL } & 0.000 & 0.000 & 0.002 & 0.002 & 0.000 & 0.000 \\
\hline & 0.001 & 0.001 & 0.001 & 0.002 & 0.001 & 0.000 \\
\hline \multirow[t]{2}{*}{ LNE } & -0.034 & -0.034 & $-0.807 *$ & $-0.807 *$ & -0.041 & -0.041 \\
\hline & 0.043 & 0.042 & 0.421 & 0.455 & 0.050 & 0.049 \\
\hline \multirow[t]{2}{*}{ CONST } & 0.332 & 0.332 & 2.713 & 2.713 & 0.298 & 0.298 \\
\hline & 0.489 & 0.542 & 3.909 & 2.221 & 0.554 & 0.562 \\
\hline$N$ & 124.000 & 124.000 & 124.000 & 124.000 & 124.000 & 124.000 \\
\hline$r 2$ & 0.146 & 0.146 & 0.166 & 0.166 & & \\
\hline r2_o & & & 0.094 & 0.094 & 0.144 & 0.144 \\
\hline
\end{tabular}

Notes. Level of significance: $* * *$ is $1 \%$; $*$ is $5 \%$; and $*$ is $10 \%$.

The number of committees has also a statistically significant relationship with the dependent variable ROAE (Table 2): The relationship is negative, so the large number of committees also affects negatively return on equity. The second research hypothesis is therefore verified. 
Discussing, finally, the third research hypothesis, it is possible to conclude that it is verified, because there is a statistically significant relationship between the number of employees and the variables that represent the credit quality and profitability of assets.

The relationship between the number of bank employees - proxy of the size of the banks, but also proxy of the complexity of the organizational structure - and credit quality is positive (Table 1), therefore the higher the number of employees - human resources working in co-operative and popular banks - the worst the credit quality.

The same negative impact can be seen also as regards the relationship between the number of employees and ROAA (Table 3): In this case, the increasing of the numerousness of human resources employed in the bank worsens ROAA.

\section{Conclusions}

The work aims to verify empirically whether and to what extent governance and human capital are able to influence performance and credit quality of banks.

The results show the absence of a dependency relationship between performance variables and the size of the board: credit quality, ROAE, and ROAA are unaffected by the size of the board.

The analysis shows the influence of the number of employees on credit quality and ROAA: a negative influence in both cases. The numerousness of human capital employed in the bank, proxy of the size, and complexity of the structure, should be limited.

An important aspect is related to the influence exerted by the presence of committees: The number of committees reflects the intention to support and assist the board of directors, but this choice may prove harmful to the extent it leads to the determination of an excessive complexity of governance, disproportionate in relation to the size of the bank and the managerial needs.

The results of the analysis show the negative impact of the increasing numerousness of the committees on performance and credit quality of banks.

The data require to reflect the weakness of the management efficiency of cooperative and popular banks and to reflect the importance of governance. It is possible to state the opportunity to limit and manage the governance complexity, limiting also the number of organisms to assist the board of directors; also firm size, and number of human resources should be appropriately limited in order to overcome structural weaknesses - related to the size and fragility of governance mechanisms - and in order to preserve the benefits of flexibility that allows to power and increase the link with the territory.

The results of the analysis and considerations expressed in terms of economics and statistics should consider, however, that the work has some limitations related to the sample size. Further developments should extend the sample size and possibly also the time horizon.

\section{References}

Abdulsamad, F., \& Zulkafli, A. (2007). Corporate governance and performance of banking firms: Evidence from Asian emerging markets. Advances in Financial Economics, 12, 49-74.

Adams, R. B., \& Mehran, H. (2003). Is corporate governance different for bank holding companies? Economic Policy Review, 9 , 123-142.

Adams, R. B., \& Mehran, H. (2005). Corporate performance, board structure and its determinants in the banking industry. Proceedings from European Finance Association Annual Meeting, Moscow. 
Adams, R. B., \& Mehran, H. (2008). Board structure, performance and organizational structure: The case of bank holding companies. Proceedings from Corporate Governance in Italia: A 10 anni dal Testo Unico della Finanza, Banca D'Italia, Roma.

Ahrens, J., Schweickert, R., \& Zenker, J. (2011). Varieties of capitalism, governance and government spending: A cross-section analysis. Kiel: Kiel Institute for the World Economy.

Ayadi, R., Schmidt, H. R., \& Carbó Valverde, S. (2009). Investigating diversity in the banking sector in Europe. Brussels: Center for European Policy Studies.

Belkhir, M. (2009). Board of directors' size and performance in the banking industry. International Journal of Managerial Finance, 5(2), 201-221.

Beltratti, A., \& Stulz, R. M. (2011). The credit crisis around the globe: Why did some banks perform better? Retrieved from http://www.ssrn.com/abstract $=1572407$

Birchall, J., \& Ketilson, L. H. (2009). Resilience of the cooperative business model in times of crisis. Geneva: International Labour Office (ILO), Sustainable Enterprise Programme.

Boscia, V., Bussoli, C., Cotugno, M., \& Stefanelli, V. (2012). Governance and peer monitoring in co-operative banks. Empirical evidence on portfolio credit risk. European Journal of Economics, Finance and Administrative Sciences, 46, 184-199.

Bussoli, C. (2013). Bcc nella crisi: Governance delle banche locali ed effetti sulla performance e sulla qualità del credito. Bancaria, 6, 28-41.

Cornett, M. M., McNutt, J. J., \& Tehranian, H. (2009). Corporate governance and earnings management at large US bank holding companies. Journal of Corporate Finance ,15, 412-430.

Drake, L., \& Llewellyn, D. T. (2001). The economics of mutuality: A perspective on UK building societies. In J. Birchall (Ed.), The new mutualism in public policy. London: Routledge.

Erkens, D. H., Hung, M., \& Matos, P. P. (2012). Corporate governance in the 2007-2008 financial crisis: Evidence from financial institutions worldwide. Journal of Corporate Finance, 18, 389-411.

Fahlenbrach, R., \& Stulz, R. M. (2011). Bank CEO incentives and the credit crisis. Journal of Financial Economics, 99, 11-26.

Fonteyne, W. (2007). Cooperative banks in Europe (IMF working paper WP/07/159). Retrieved from https://www.imf.org/external/pubs/ft/wp/2007/wp07159.pdf

Goglio, S., \& Alexopulos, Y. (2014). Editorial: Cooperative banks at a turning point? Journal of Entrepreneurial Organizational Diversity, 3(1), 1-8.

Groeneveld, J. M., \& De Vries, B. (2009). European cooperative banks: First lessons of the subprime crisis. The International Journal of Cooperative Management, 4(2), 8-21.

Grove, H., Patelli, L., Victoravich, L. M., \& Xu, P. (2010). Corporate governance and performance: Evidence from US commercial banks. Proceedings from Midwest Finance Association Meeting, Las Vegas.

Jassaud, N. (2014). Reforming the corporate governance of Italian banks. Retrieved from https://www.imf.org/external/pubs/ft/wp/2014/wp14181.pdf

Larcker, D. F., Richardson, S. A., \& Tuna, A. I. (2007). Corporate governance, accounting outcomes, and organizational performance. The Accounting Review, 82(4), 963-1008.

Love, I., \& Rachinsky, A. (2007). Corporate governance, ownership and bank performance in emerging markets: Evidence from Russia and Ukraine. Retrieved from http://siteresources.worldbank.org/DEC/Resources/Corporate_Governnace_Ownership_and_Bank_Performance.pdf

Mayur, M., \& Saravanan, P. (2006). Does the board size really matter? An empirical investigation on the Indian banking sector. Journal of Corporate Governance, 5(2), 1-17.

Mottura, P. (2011). Banche cooperative e crisi finanziaria. Forme istituzionali da valorizzare con modelli di governance appropriati. Bancaria, 12, 2-25.

Peni, E., \& Vähämaa, S. (2011). Did good corporate governance improve bank performance during the financial crisis? Journal of Financial Services Research, 41, 11-35.

Weisbach, M. (1988). Outside directors and CEO turnover. Journal of Financial Economics, 20, 431-460. 